\title{
矩形形状を有する波形鋼板のせん断弾性座屈耐力評価 EVALUATION OF ELASTIC BUCKLING STRENGTH OF RECTANGULAR CORRUGATE PLATE UNDER SHEAR LOADING
}

\author{
五十嵐規矩夫*, 藤 澤 逸 志**, 清 水 信 孝*** \\ Kikuo IKARASHI, Masashi FUJISAWA and Nobutaka SHIMIZU
}

\begin{abstract}
This report deals with the parametric analysis of elastic shear buckling done by F.E.M. program in order to evaluate shear buckling behavior of rectangular corrugate plates accurately. The results calculated by F.E.M. program are compared with those given by existing formula and calculated by energy method analysis and the differences between rectangular corrugate plates and anisotropic plates are examined. Furthermore, using ratio of the moment of inertia, the influences of cross-sectional shapes and boundary conditions of rectangular corrugate plates are understood in some degree, and new approximate formulas to evaluate the elastic buckling strength are suggested.
\end{abstract}

Keywords: Rectangular corrugate plate, Elastic shear buckling, F.E.M. analysis, Energy method analysis, Coupled buckling, Boundary condition 矩形波形鋼板, せ几断弾性座屈, 有限要素法解析, エネルギー法解析, 連成座屈, 境界条件

\section{1. 序}

薄鋼板を折り曲げ形成してなる折板や波板に代表される波形鋼板 はその幾何学的形状特性から, 従来積雪や風力等の面外力に抗する 目的で, 屋根材や壁材など建築構造物における面材として利用され てきた。近年では, せん断特性における高い剛性, 強度を有効活用 する試みも見られ，欧米においては「Stressed Skin Diaphragm Design」が確立され，屋根材へ適用寸ることで水平ブレースを省略 した設計が可能となっている ${ }^{1,2)}$.また, 土木分野においては合理的 かつ施工性に優れた波形鋼板ウェブPC複合橋がヨーロッパを皮切 りに国内でも数多く建設され3), それらを建物の, 制振, 耐震要素 として使用寸るための研究も行われ始めている4) 7).さらに, 薄鋼 板を用いた構造材の新たな可能性の探求, 開発もなされてきており 8), 今後も波形鋼板は構造材料として発展が期待されている.

しかし,波形鋼板のせん断挙動は複雑で未だ十分に明らかにされ ているとは言い難い. そのせん断座屈については理論的に材料異方 性を有する平板として取り扱われている場合が多いものの, 現実に は断面の崩れ等により材料異方性平板とは異なる挙動を示す可能性 を有していると考えられる.例えば波形鋼板が面内せん断力を受け た場合, (a) 全体座屈, (b)波形を構成する帯板内での局部座屈, (c) 局部座屈と全体座屈による連成座屈, の発生状況は波形形状により 異なる.特に(c)の連成座屈は危険性が指摘されているものの9), そ
れらを詳細に検討した文献は著者の知る限り見受けられない. 以上 のように今後も波形鋼板のせん断座屈挙動については詳細に検討し ていく必要があると考えられる.

本研究では波形鋼板のせん断座屈耐力を正確に評価することを目 的として, 矩形形状を有する波形鋼板について, 有限要素法を用い たパラメトリック解析を行う.種々の波形形状及び周辺支持条件が せん断弾性座屈耐力及び座屈モードに及ぼす影響について, 曲げ剛 比を用いて検討する.特に本論文では, 全体座屈に着目し, 全体座 屈挙動を把握するとともに,そのおこり得る範囲をある程度明確に した上で全体座屈耐力の近似評価を試みる.また, 既往の評価式や 新たに行ったエネルギー法を用いた理論解析との比較を行うことに より,波形鋼板のせん断弾性座屈耐力を理論的に異方性平板で取り 扱うことが妥当であるかを検討し, 数值解析結果とそれら $2 つ$ つ評 価手法の差異についても論じる.

\section{2. 波形鋼板のせん断弾性座屈耐カに関する既往の評価式}

通常, 波形鋼板の全体座屈は, 直交異方性平板として取り扱うこ とにより座屈耐力の評価が試みられることが多い, 例えば, Easley ら ${ }^{10}$ は四辺単純支持の場合について,そのせん断座屈応力度を次の 式で与えている.

\footnotetext{
$*$ 東京工業大学大学院理工学研究科建築学専攻 准教授・博士 (工学)

** 元東京工業大学大学院理工学研究科建築学専攻 修士(工学)

*** 新日本製鐵侏鋼構造研究開発センター 主任研究員・工修 東京工業大学大学院理工学研究科建築学専攻 博士後期課程 (社会人コース)

Assoc. Prof., Dept. of Arch. and Building Eng., Tokyo Institute of Technology, Dr. Eng.

Graduate Student, Dept. of Arch. and Building Eng., Tokyo Institute of Technology, M. Eng.

Senior Researcher, Steel Structure Development Center, Nippon Steel Corp., M. Eng. Graduate Student, Dept. of Arch. and Building Eng., Tokyo Institute of Technology
} 


$$
\tau_{c r}=36 \frac{\sqrt[4]{D_{x}^{3} D_{y}}}{A^{2} t}
$$

ここで, $A$ : 波に平行な方向のパネル長さ, $t$ : 板厚, $D_{x}, D_{y}$ : 強, 弱 軸の板の曲げ剛度である. 式(1)は, 四辺単純支持の座屈モードの たわみWの一般式を以下の式(2)で仮定しエネルギー法を用い,さ らに, $D_{x}$ が $D_{y}$ よりも十分に大きいことからその算出式を減じ簡略 化することで導かれたものである.

$$
W=A_{s} \sin \frac{\pi x}{A} \sin \frac{n \pi}{B}(y-\rho x)
$$

ここで, $A_{s}$ : 節線で区切られる半波の振幅, $B$ : 波に直行方向のパネ ル幅, $n$ : 節線で区切られる半波の数, $\rho$ : 節線勾配である. 式(1) は $D_{x} / D_{y}>200$ の範囲で単純化され得られたもので, 簡略化しない場 合との誤差は $2 \%$ 以下である.その後, Easleyは, 式(1)とBergmann $ら^{10)}$ 及びHlavacek $\left.{ }^{11}\right)$ の提唱する2式とを比較検討し, 更に, 実験を 行うことで, 上下端部を剛結した場合の座屈強度が, 単純支持の場 合の1.9倍となることから, 上式を拡張させた以下のせん断座屈強 度算定式を導いている ${ }^{12}$.

$$
\tau_{c r}=36 r \frac{\sqrt[4]{D_{x}^{3} D_{y}}}{A^{2} t}
$$

ここで, $r$ は境界の回転拘束に関する係数であり, 単純支持の場合 $r=1.0$, 固定支持の場合 $r=1.9$ となる.なお, Easleyは, 現実的な波 形鋼板パネルの境界の回転拘束の度合は, 周囲の剛体枠で掴まれる パネル縁の幅によるものとしている.また, 強, 弱軸の板剛度 $D_{x}$, $D_{y}$ は実験的に以下の式で与えられる。

$$
D_{x}=\frac{E I_{x}}{l}, \quad D_{y}=\frac{E t^{3} l}{12 w}
$$

ここで, $I_{x}$ : 波形断面一山当たりの中立軸に対寸る断面二次モーメ ント, $l$ : 波形断面一山の波幅, $w$ : 波形断面一山の波の全長さであ る. 局部座屈については, 板の折り曲げ点をヒンジとした, 四辺単 純支持のせん断座屈として取り扱うことができ, 以下の式で算出さ れる13).

$$
\tau_{c r, \mathrm{~L}}={ }_{4 \mathrm{P}} k_{\tau, \mathrm{L}} \frac{\pi^{2} E}{12\left(1-v^{2}\right)}\left(\frac{t}{A}\right)^{2}
$$

ここで, ${ }_{4 \mathrm{P}} k_{\tau, \mathrm{L}}$ : 四辺単純支持のせん断座屈係数 $\left({ }_{4 \mathrm{P}} k_{t, \mathrm{~L}}=4.00+5.34 /\right.$ $\left.\lambda_{k}^{2}\right), \lambda_{k}$ : 帯板の縦横比 $\left(\lambda_{k}=\max (a, b, 2 d) / A\right)$ である.

\section{3. 有限要素法を用いた波形鋼板の数値解析概要}

本研究における解析には汎用非線形構造解析プログラムABAQUS / Standard Version 6.5-6を用いている. 以後, 本論文では, この ABAQUSによる解析を単に数值解析と呼ぶ. 本研究で対象と寸る波 形鋼板は矩形形状を有するものであり,解析モデルの一例を図1に 示寸. 試験体は4節点シェル要素で構成し, 試験体の各辺に十分に 高い剛性を有する剛体枠を配し, 試験体の隅角部と剛体枠をピン支 持しせん断力を作用させた. 波形を構成する帯板は, 局部座屈の発 生を考慮し，4要素以上に分割している. パネル形状は辺長比 $\lambda=1$ の正方形平板を対象とし,その強軸方向長さは $A=1000 \mathrm{~mm}$ である.

図 2 に波形断面寸法を, 図3 に試験体名定義を示す.本研究では, 図4及び表 1 に示寸ように試験的に5つの断面タイプのモデルを作 成している.表 1 中のBは図 1 に示寸ように波に直行方向のパネル 幅であり, $N$ は波数である.lは単位波の幅であり, 波数 $N$ にり異

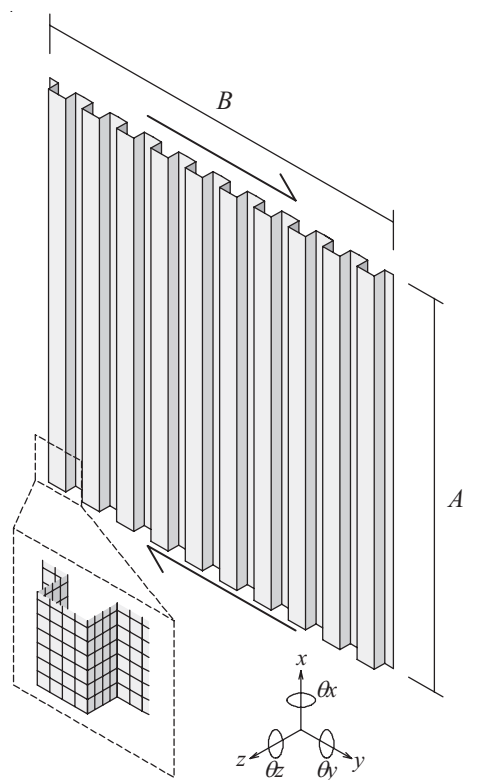

図1 解析モデル例

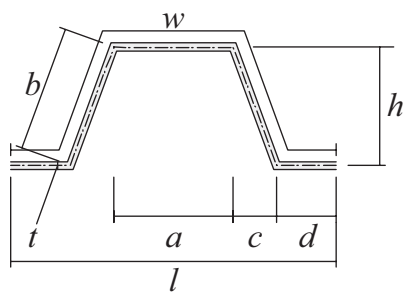

図2 波形断面寸法定義

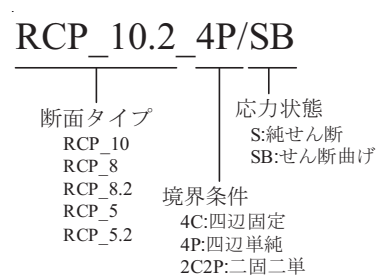

図3 試験体名定義

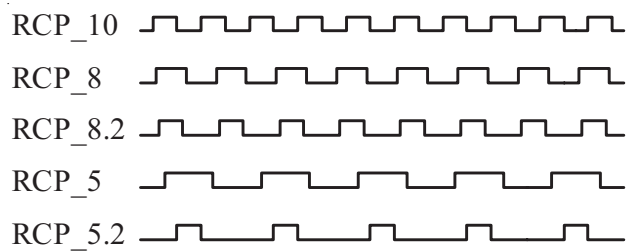

図4 断面タイプ

表1 断面タイプの寸法

\begin{tabular}{cccccccc}
\hline Section & $B[\mathrm{~mm}]$ & $N$ & $l[\mathrm{~mm}]$ & $a[\mathrm{~mm}]$ & $b[\mathrm{~mm}]$ & $c[\mathrm{~mm}]$ & $d[\mathrm{~mm}]$ \\
\hline RCP_10 & $A$ & 10 & $B / N$ & $l / 2(=50)$ & $h$ & 0 & $l / 4$ \\
RCP_8 & $A$ & 8 & $B / N$ & $l / 2$ & $h$ & 0 & $l / 4$ \\
RCP_8.2 & $A$ & 8 & $B / N$ & 50 & $h$ & 0 & $(l-a) / 2$ \\
RCP_5 & $A$ & 5 & $B / N$ & $l / 2$ & $h$ & 0 & $l / 4$ \\
RCP 5.2 & $A$ & 5 & $B / N$ & 50 & $h$ & 0 & $(l-a) / 2$ \\
\hline
\end{tabular}

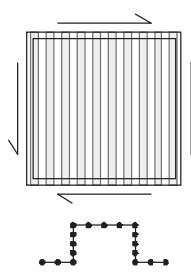

(a) $4 \mathrm{C} / \mathrm{S}$
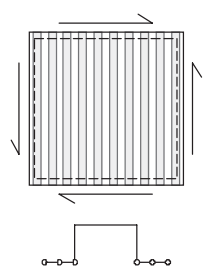

(b) $4 \mathrm{P} / \mathrm{S}$
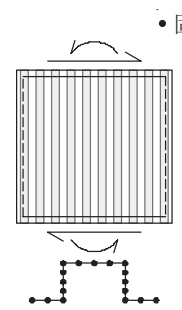

(c) $2 \mathrm{C} 2 \mathrm{~B} / \mathrm{SB}$ 固定支持。単純支持

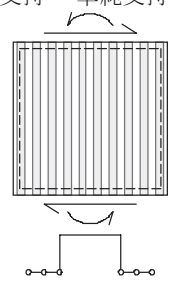

(d) $4 \mathrm{P} / \mathrm{SB}$

図5 境界条件及び応力状態

なる.また $a, b, c, d$ は, 図 2 に示す波形断面の諸寸法である. 波数 $N=10$ かつ上下帯板幅が等しいRCP_10 基本形とし、RCP_8, RCP_5 は上下帯板幅の関係を等しくし波数を変化させ, RCP_8.2, RCP_5.2は上部帯板幅をRCP_10 と等しく一定とし波数を変化させ 


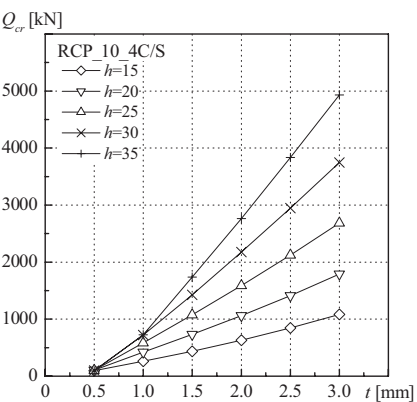

(a) $\mathrm{RCP} \_10 \_4 \mathrm{C} / \mathrm{S}$

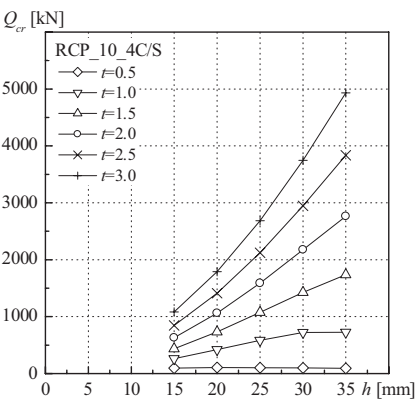

(a) $\mathrm{RCP} 10 \quad 4 \mathrm{C} / \mathrm{S}$

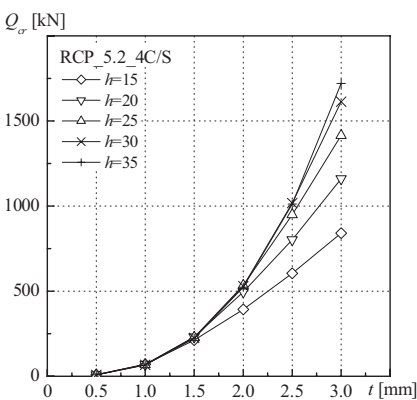

(b) $\mathrm{RCP} 5.24 \mathrm{C} / \mathrm{S}$

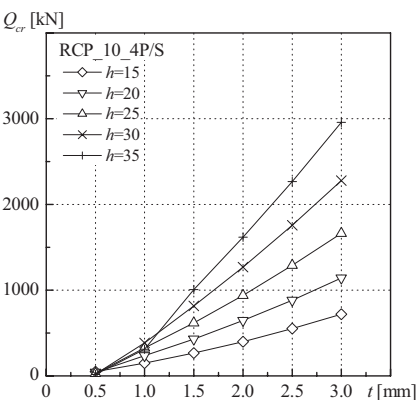

(c) RCP_10_4P/S

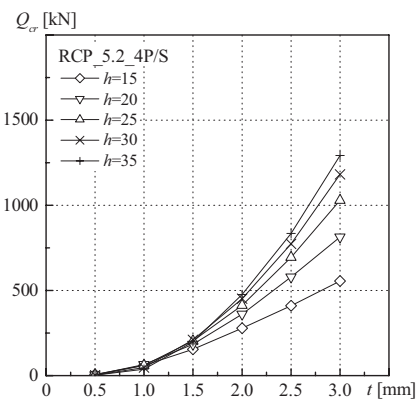

(d) $\mathrm{RCP} 5.2 \_4 \mathrm{P} / \mathrm{S}$

図 6 座屈耐力-板厚

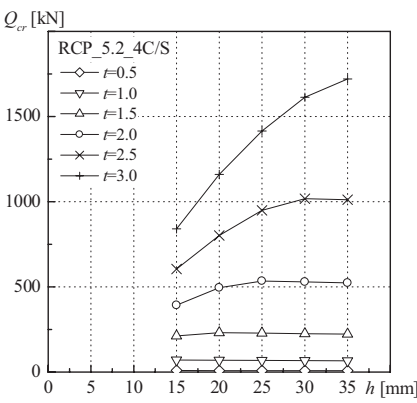

(b) RCP_5.2_4C/S

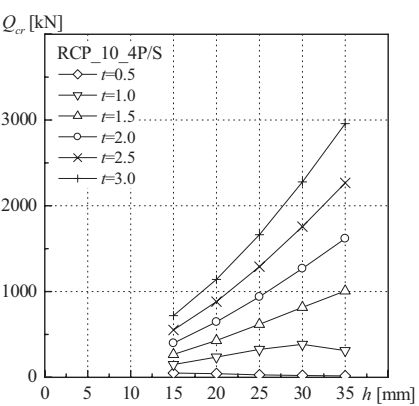

(c) $\mathrm{RCP} 10 \quad 4 \mathrm{P} / \mathrm{S}$

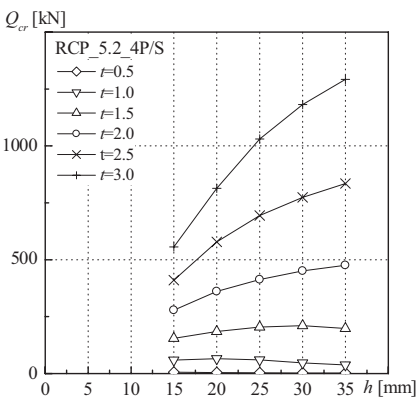

(d) $\mathrm{RCP} 5.24 \mathrm{P} / \mathrm{S}$

図 7 座屈耐力-波高

ている. 形状パラメーターは. 板厚 $t$ 、波高 $h$ であり, デッキプレー 卜, 屋根材から耐震壁に至るまで, 現実的な板厚と波高の範囲を網 羅するよう設定している.なお本研究で対象とする波形は矩形のみ とし, 図 2 において $c=0$ の場合のみを取り扱う.本論文では, 波形 の基本形として $c=0$ の場合を検討する必要があるという立場であり, その座屈性状を把握できれば, $c=0$ 以外の場合も, $c=0$ の結果をもと に評価可能であると考えている. その評価は今後の課題としたい.

境界条件は図 5 に示寸ように, 基本形となる四辺固定 $(4 \mathrm{C} / \mathrm{S})$, 四 辺単純 $(4 \mathrm{P} / \mathrm{S})$ に加え, それらの $x$ 軸に平行な 2 辺の面内変位のみを 許容した二辺固定二辺単純 $(2 \mathrm{C} 2 \mathrm{P} / \mathrm{SB})$ 、四辺単純 $(4 \mathrm{P} / \mathrm{SB})$ の計 $4 つ$ としている.なお, 波形断面端部を単純支持とする際には, 平板と しての挙動を十分に模す為, 波形の下部帯板のみを単純支持とし, 側部、上部は拘束していない.

また, 材料の Young 率 $E=2.05 \times 10^{5} \mathrm{~N} / \mathrm{mm}^{2}$, Poisson 比 $v=0.3$ と している.以上のような数值解析から得られる線形固有值をもとに 矩形形状を有する波板鋼板のせん断弾性座屈耐力を算出する.

\section{4. 波形鋼板のせん断座屈耐力}

\section{1 波形形状がせん断座屈耐力に与える影響}

数值解析より得られたせん断弾性座屈耐力について板厚, 波高の 影響を見る. 図6にせん断座屈耐力と板厚の関係を示寸. 各試験体 とも, 板厚の増加に伴いせん断座屈耐力は放物線状に増加してい る. 板厚の厚い範囲では波高が高い程座屈耐力は高くなっている が, 板厚の薄い範囲では一部で波高が高いものの方がせん断座屈耐 力が低くなっている.図7に示寸よう, 波高を横軸にとって見ると, 板厚が厚いものでは, 波高が増加するにつれ板厚と同様に法物線状 に単調に増加が見られたが, 板厚が薄いものについては, 波高が増 加寸るとある点を境に座屈耐力は減少していく傾向にある.これ

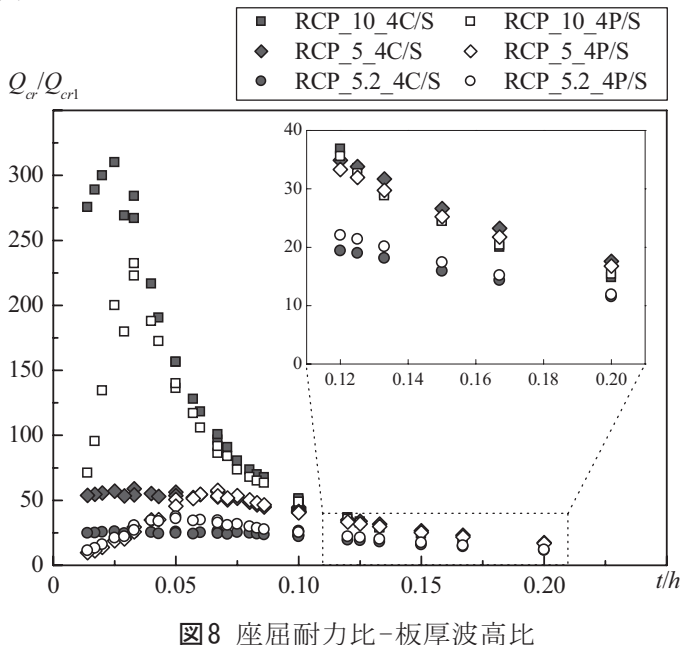

は, 局部座屈ないし連成座屈が生じたためであり, 形状によっては 波高が高い方が連成の度合いが強くなり座屈耐力の低下を生じる危 険性を有することを意味する.

これらの座屈耐力を板厚波高比 $(t / h)$ で整理する.板厚波高比は, 波形鋼板の波形形状の度合を示寸一指標であり, 值が大きくなるほ ど平板に近い形状を意味する。図8は縦軸に平板と見なした場合の 座屈耐力 $Q_{c r}$ で除した波形鋼板の座屈耐力を, 横軸に板厚波高比を とっている，図より，RCP_10_4C/S，RCP_10_4P/Sでは，板厚波 高比 $(t / h)$ が約 0.03 より大きい範囲において概数反比例的に座屈耐 力比は減少しており，RCP_5_4C/S, RCP_5_4P/S, RCP_5.2_4C/ S, RCP_5.2_4P/Sでは板厚波高比が約0.07より大きい範囲において 概ね反比例的に座屈耐力比は減少していることがわかる.この反比 例的に座屈耐力が減少している範囲では,いずれの断面タイプにお いても全体座屈による崩壊である.

一方, RCP_10_4C/S，RCP_10_4P/S は, 板厚波高比が約 0.03 よ 
り小さい範囲において板厚波高比の増加とともに座屈耐力が上昇し ており，RCP_5_4C/S, RCP_5_4P/S, RCP_5.2_4C/S, RCP_5.2_4P/S では板厚波高比が約 0.07 より 小さい範囲においては, 板厚波高比の 増加とともに座屈耐力は緩やかに上昇あるいは, 板厚波高比によら ず座屈耐力はほぼ一定で推移している.この範囲では,いずれの断 面タイプにおいても局部座屈あるいは連成座屈が生じている. しか し,この範囲における座屈耐力比と板厚波高比の関係は断面タイプ により異なる.

矩形波形鋼板が面内せん断力を受けた場合, この板厚波高比を用 いることで, その波形鋼板が全体座屈するか否かは概㸚判断でき, その範囲における座屈耐力の減少傾向も把握できる. しかし, その板 厚波高比の境界值及び座屈耐力の減少割合は断面タイプにより異な り, それらを包括的に評価する指標を導入する必要がある.

\section{2 せん断座屈耐力の既往の評価式との対応}

図9に全試験体の解析結果から, 全体座屈及び連成座屈(全体座屈 が卓越しているものに限る)を形成する試験体における, 数值解析 結果とEasleyの評価式(3) との対応を示す. なお, モード判別は視 認により行っており, 座屈耐力に拘らず, 座屈波形が試験体の波形 に拘束されることなく全体にわたり生じているものを全体座屈, 座 屈波形が帯板の中のみに生じているものを局部座屈, それ以外のも のを連成座屈としている. 図より, 境界条件が $4 \mathrm{C} / \mathrm{S}, 4 \mathrm{P} / \mathrm{S}$ とも, 数值解析結果のうち, 黒塗りプロットで示している全体座屈したも のは, その座屈耐力が評価式を上回る結果となったが, 相関性は有 している.一方, 白抜きプロットで示した連成座屈しているものは 一部評価式を下回るものもある.これはEasleyの評価式が全体座屈 する場合の座屈耐力を与える式であるためである.

ここで数值解析から得られた全体座屈する場合の座屈耐力が Easleyの評価式を上回る要因については, 次のように考えている. Easleyの評価式は近似式であり, また, 想定する座屈波形のたわみ 関数についても, 波形断面端部の境界については境界条件を満たす が他の二辺については条件を満たしていない.さらに, 四辺固定支 持の場合の座屈耐力は, 四辺単純支持の場合から実験的に 1.9 倍す るのみに留まっているため, 若干正確性に欠けるおそれは否めな い. 従って, 本研究では新たにエネルギー法による理論解析を行い, 数值解析結果との対応をより精度良く評価することを試みる.

\section{3 エネルギー法を用いた新たな理論解析と数值解析結果との対応}

本研究で提案するエネルギー法による理論解析のモデルを図10に 示寸.また, その際に用いられるパラメーターの定義を表 2 に示寸. 板の面外変形に伴うひずみエネルギー $\Delta U$ 及び曲げせん断力がなす 仕事 $\Delta T$ を次式で表す ${ }^{14)}$

$$
\begin{aligned}
\Delta U & =\frac{1}{2} \int_{0}^{A} \int_{0}^{B}\left[D_{x}\left(\frac{\partial^{2} w}{\partial x^{2}}\right)^{2}+D_{y}\left(\frac{\partial^{2} w}{\partial y^{2}}\right)^{2}+2 D_{x y} v \frac{\partial^{2} w}{\partial x^{2}} \frac{\partial^{2} w}{\partial y^{2}}\right. \\
& \left.+2 D_{x y}(1-v)\left(\frac{\partial^{2} w}{\partial x \partial y}\right)^{2}\right] d x d y
\end{aligned}
$$

$\Delta T=\frac{1}{2} \frac{\lambda}{\eta \beta} \tau_{c r} t \int_{0}^{A} \int_{0}^{B}\left(1-\frac{\beta}{\alpha} x\right)\left(1-\frac{2}{B} y\right)\left(\frac{\partial w}{\partial x}\right)^{2} d x d y$

$$
+\frac{1}{2} \tau_{c r} t \int_{0}^{A} \int_{0}^{B}\left[1-\frac{1}{6 \eta}+\frac{y}{\eta B^{2}}(B-y)\right] \frac{\partial w}{\partial x} \frac{\partial w}{\partial y} d x d y
$$

ここで, 変位関数 $W$ は下のようにおく.

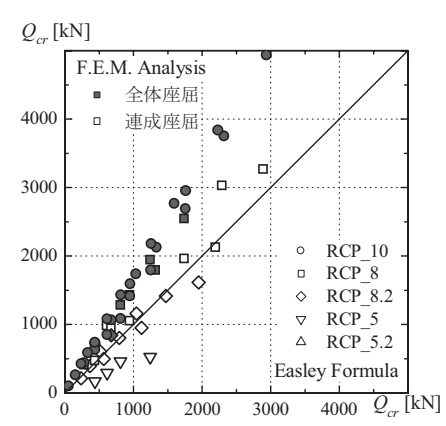

(a) 四辺固定 $(4 \mathrm{C} / \mathrm{S})$

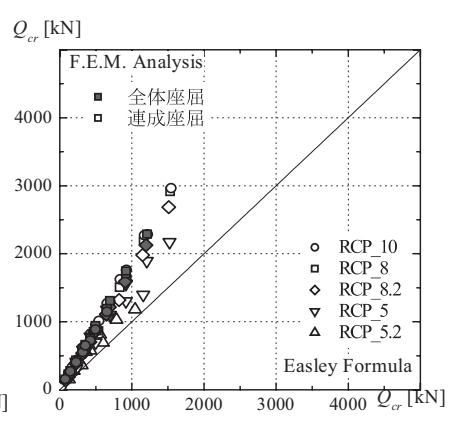

(b) 四辺単純 $(4 \mathrm{P} / \mathrm{S})$
図 9 数值解析結果と Easley式の対応

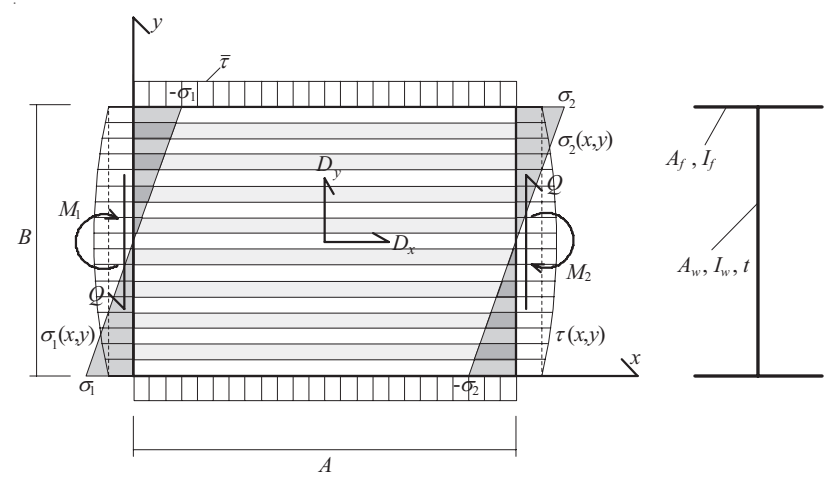

図10 理論解析モデル

表2 理論解析パラメーター設定

$D_{x}, D_{y}: x, y$ 方向の板の単位幅当たりの曲げ剛性; $D_{x y}$ : 㧖り剛性; $\lambda$ : 辺長比 $(=A / B) ; \beta$ : 曲げ勾配; $\eta$ : せん断曲げ比 $\left(\eta=\frac{A_{f}}{A_{w}}+\frac{1}{6}\right)$; $a$ : 応力比 $(\alpha=\eta \beta / \lambda) ; A_{f}, A_{w}$ : フランジ, ウェブの断面積;

$I_{f}, I_{w}$ : フランジ, ウェブの断面二次モーメント

$\sigma(x, y)$ : 曲げ応力度分布: $\sigma(x, y)=\sigma \cdot\left(1-\frac{\beta}{A} x\right)\left(1-\frac{2}{B} y\right)$; $\tau(x, y)$ : せん断応力度分布: $\tau(x, y)=\frac{\beta}{\lambda}\left\{\left(\eta-\frac{1}{6}\right)+\frac{y}{B^{2}}(B-y)\right\} \sigma$ ； $\bar{\tau}:$ 平均せん断応力度 : $\bar{\tau}=\frac{\beta \eta \sigma}{\lambda}$;

$$
W=\sum_{m} \sum_{n} a_{m n} u_{m} v_{n}
$$

四辺固定 $(4 \mathrm{C} / \mathrm{S}): u_{m}=\sin \frac{m \pi x}{A} \sin \frac{\pi x}{A} ; v_{n}=\sin \frac{n \pi y}{B} \sin \frac{\pi y}{B}$

四辺単純 $(4 \mathrm{P} / \mathrm{S}): u_{m}=\sin \frac{m \pi x}{A} ; v_{n}=\sin \frac{n \pi y}{B}$

ここで, $m, n$ はそれぞれ $x, y$ 方向の半波の数, $a_{m n}$ は各級数項にお ける係数である. 本研究では, 純せん断及び逆対称曲げを対象とし ているため, 曲げ勾配は $\beta=2$ と寸る. せん断曲げ比 $\eta$ は, 応力度分 布における平均せん断応力度と最大曲げ応力度の関係に寄与寸るも のである ${ }^{15}$. 境界条件が $4 \mathrm{C} / \mathrm{S}$ 及び $4 \mathrm{P} / \mathrm{S}$ の場合, 純せん断場を想定 しているため, せん断曲げ比 $\eta$ は無限大としている. 式 (6) と式 ( 7 ) からせん断弾性座屈応力度 $\tau_{c r}$ を最小にする条件より, 式 ( 8) 中の係数 $a_{m n}$ からなる一次同時方程式の係数行列を作り, その行列 より一般化固有值問題としてせん断弾性座屈耐力を求める. 以後, このエネルギー法による理論解析を本論文では単に理論解析と呼ぶ. 
本理論解析は, Easleyの評価式に比して以下の点でより正確且つ 汎用的に評価可能であると考えられる.

1. 曲げ剛比の大きさによらない.

2. 四辺単純支持を,波形断面に垂直な二辺の境界条件も考慮.

3. 四辺固定についてもたわ夕関数を提示.

4. 辺長比の長い試験体についても対応.

この理論解析結果と数值解析結果の対応を図11に示す.図より, 一部連成座屈する場合に理論解析結果を下回るものもあるが, 四辺 固定, 四辺単純とも黒塗りプロットで示した数值解析から得られた 全体座屈寸る場合の座屈耐力は理論解析結果よりも高く,図9に示 寸Easleyの評価式との場合と対応が概漦一致した.従って,波形鋼 板のせん断座屈耐力は, 曲げ剛性を考慮した異方性平板と見なした 理論解析値よりも高い值を示すことが確認できる.

ここで, Easley評価式において四辺固定, 四辺単純の比を1.9倍 としていることについて若干ながら言及する. 図12 に数值解析結 果及び理論解析結果の, 同形状における $4 \mathrm{C} / \mathrm{S}, 4 \mathrm{P} / \mathrm{S}$ の座屈耐力比 ${ }_{4 \mathrm{C}} Q_{c r, \mathrm{G}}{ }_{4 \mathrm{P}} Q_{c r, \mathrm{G}}$ と板剛度比 $D_{x} / D_{y}$ の関係を示す. 図中には, Easley評価 式の座屈耐力比 $(=1.90)$ 及び, 平板の場合の座屈耐力比 $(=1.55)$ も実 線で示してある. 図より, 数值解析結果, 理論解析結果ともに, 板 剛度比が大きくなるほど座屈耐力比が大きくなる傾向にあり， Easleyは実験等の比較によりその比を一律に1.9としているが, 理 論解析結果では板剛度比が低い場合 1.75 , 高い場合でも 1.8 程度と する必要があると考えられる.数值解析結果について見ると, 数值 解析結果も理論解析結果と同様の傾向を呈し, 板剛度比が大きい範 囲ではその比は1.8に近づくが, 板剛度比が小さい範囲では1.75を 下回り, 平板の場合の 1.55 をも下回る試験体も見られた。これは, 数值解析において四辺単純支持は波形の下部帯板のみを支持してい るからであり, 異方性の度合が弱くなるほど下部帯板のみを支持す ることによる座屈耐力の低下の影響が大きくなる.

\section{4 数値解析結果が理論解析結果を上回る要因の検討}

数值解析より得られる波形鋼板のせん断座屈耐力が異方性平板の 理論解析結果を上回る要因について検討する. 図13に理論解析結 果に対する数值解析結果の比と板剛度比の関係を示す.座屈モード が全体座屈を形成するものについて見ると,板剛度比が小さいもの ほど, 即ち形状が平板に近いものほど数值解析結果と理論解析結果 の相対的な差は小さく, 板剛度比が大きいものほどその差は大きく なり, およそ2倍弱に収束していく. 連成座屈するものに関しては, 全体座屈の場合とは異なり板剛度比が大きくなるにしたがい座屈耐 力が低下していく.この傾向は, 断面タイプごとに捉えられるが, 統一的な傾向を捉えるのは難しい.

続いて, 荷重偏心が座屈耐力に及ぼす影響について考察する.本 研究で対象としている試験体は荷重作用軸と波形断面の中立軸が異 なる上, 板の 2 辺の中立軸位置もそれぞれ異なる. $4 \mathrm{C} / \mathrm{S} の$ 場合には 波形断面の節点は全て剛体枠に剛結されているため影響はないが, 4P/Sの場合には波形溝帯板のみしか単純支持されていないため, 面 外曲げ等の荷重偏心の影響を受けるおそれがある.従って, 図14に 示すようにRCP 10 を基に, 中立軸と荷重作用軸と波形断面の中立 軸が等しい, 面外二方向に凸の形状のRCP 10 'を同数作製(但し, 板 剛度比は異なる) し, 解析を行った. その結果を図15 亿示寸. 図よ り，4C/S，4P/S ともにRCP 10 と RCP 10 それぞれの理論解析結

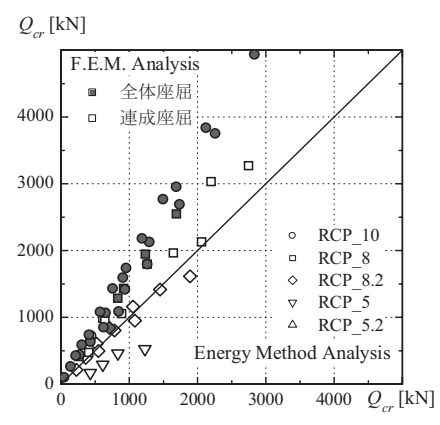

(a) 四辺固定 $(4 \mathrm{C} / \mathrm{S})$

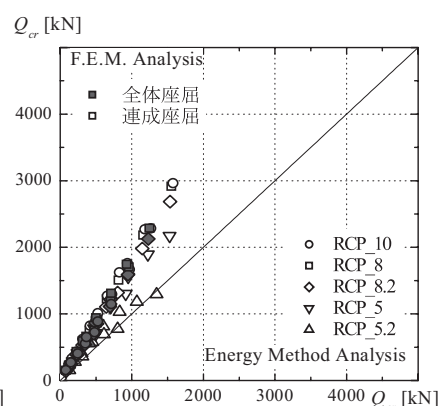

(b) 四辺単純 (4P/S)
図11 数值解析結果と理論解析結果の対応

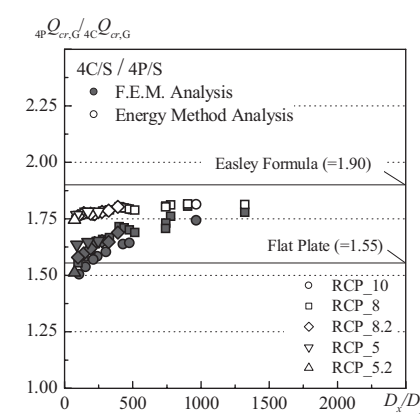

図12 エネルギー法解析結果と Easley式の比較

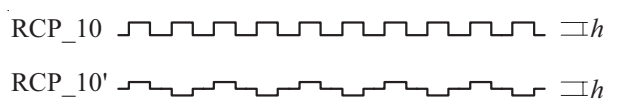

図14 荷重偏心を考慮した断面タイプ

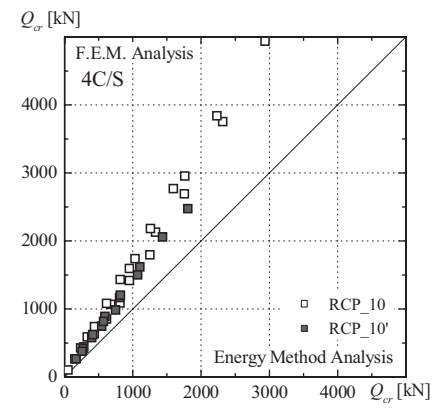

(a) $4 \mathrm{C} / \mathrm{S}$

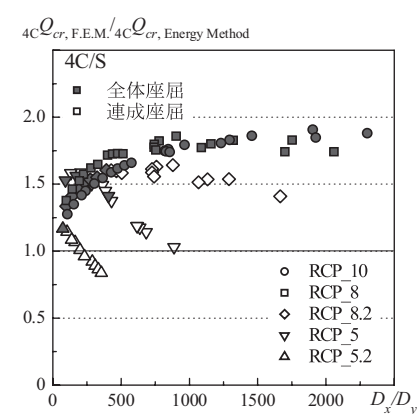

図13 四辺単純と四辺固定の比

\section{.}


また, 据り剛性の影響についても検討する.波形鋼板の場合, 異 方性平板にはない特有の㨭り剛性の影響により, 座屈耐力が上昇す る可能性があるが, 評価式(3)自体には据り剛性の影響は考慮され ていない.そこで㨝り剛性がせん断座屈耐力に及ぼす影響について 考察するため, 板剛度比が $D_{x} / D_{y}=1,100,1000$ それぞれの場合の, 据り剛性をパラメーターとして理論解析を行った. 図16はせん断座 屈係数と据り剛性の関係について示している.据り剛性は平板の据 り剛性Dで除している. 図より, 全ての板剛度比の場合について, 㨝り剛性の増加に伴うせん断座屈係数の変化は小さく, 本理論解析 の範囲では, 㨝り剛性がせん断座屈係数に与える影響は小さいことが わかる。

最後に,波形鋼板の波形断面端部を全て単純支持とした場合のせ

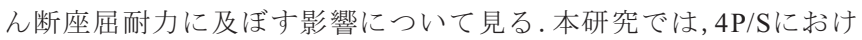
る波形断面端部の支持を, 平板としての挙動を模すため, 溝部のみ を単純支持しているが, 今回新たに波形断面端部の全ての節点を単 純支持した場合の境界条件 $4 \mathrm{P}^{\prime} / \mathrm{S}$ を作成し, 数值解析を行った。境 界条件 $4 \mathrm{P}^{\prime} / \mathrm{S}$ は, Easleyの示寸四辺単純支持により近い, それらと 四辺固定支持 $(4 \mathrm{C} / \mathrm{S})$ の比を図 17 に示寸. 図より, 全ての波形断面 端部の節点を単純支持した場合, 今回検討対象としている波形形状 の範囲においては, 全ての試験体について $4 \mathrm{C} / \mathrm{S}$ と座屈耐力はほぼ 等しく, 曲げ剛比が低い場合においてもその差は $2 \%$ 程度である.し たがって, 全ての波形断面端部を単純支持とすると, 側帯板の存在 により, 平板としての単純支持の挙動よりも高い值を示し, Ealsey が提唱する座屈耐力值を大きく上回る.

数值解析結果が理論解析結果を上回る要因を現段階では十分に把 握しきれていない.これは, 理論解析がある程度の仮定の上で成り 立っているためであり, 現段階では, 理論解析に組み込んでいない 波板の側面のせん断抵抗すなわちパネルの面外抵抗の存在がその可 能性としてあげられる.また本理論解析では㧖り抵抗を既往の研究 10) と同様に与えているが, 波板の現実的な㨝り抵抗を理論解析に取 り込む場合についても, その算定值について未だ不明確な部分もあ るのは確かである.従って, 今後はこれらの影響について検討, 評 価する必要があると考えている.

\section{5. 曲げ剛比を用いたせん断座屈耐力評価}

\section{1 板厚, 波高の影響}

前章より,波形鋼板のせん断座屈耐力は異方性平板として扱う理 論解析值よりも高い值を示すことが確認された. 本章では数值解析 により波形鋼板のせん断座屈耐力を曲け剛比を用いて評価すること を試みる.座屈耐力は以下で与えられるせん断座屈係数 $k_{\tau}$ で表す.

$$
k_{\tau}=\frac{12\left(1-v^{2}\right)}{\pi^{2} E \bar{A}_{w}}\left(\frac{B}{t}\right)^{2} Q_{c r} \quad \ldots \ldots \ldots(11)
$$

ここで, $\bar{A}_{w}$ :試験体の波形端部断面を平板と見なした場合の断面積 $(=B t)$ である.また, 曲げ剛比は波形鋼板の強, 弱軸方向の波形一 山当たりの断面二次モーメントの比とし, 以下の式で表される.

$$
\frac{I_{x}}{I_{y}}=\frac{(a+2 d) t^{2}+2 b h^{2}+3 b(h-2 e)^{2}+12 a(h-e)^{2}}{l t^{2}} \quad \cdots(1
$$

ここで, $e$ : 波形断面における波形溝部から中立軸までの距離であ り,その他の波形形状に関寸る記号については図2を参照されたい。 まず, せん断座屈耐力が曲げ剛比 $I_{x} / I_{y}$ を用いて評価可能かを検討

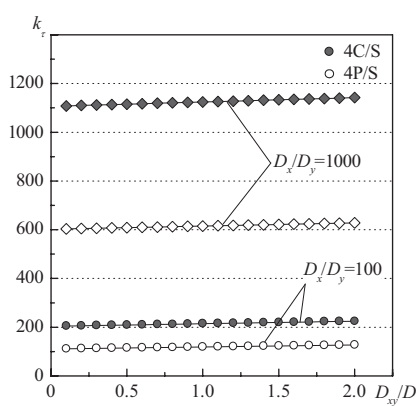

図 16 㨭り剛性 $D_{x y}$ の影響

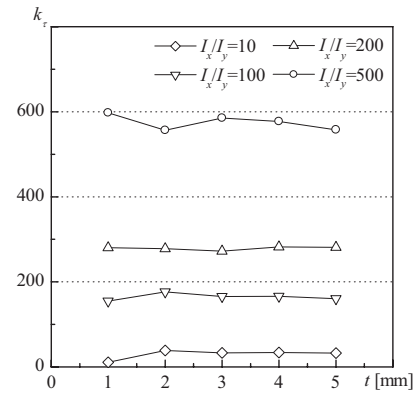

(a) せん断座屈係数 - 板厚

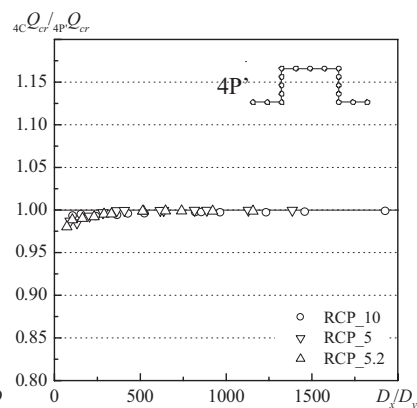

図17 全ての境界条件をピン支持と した場合

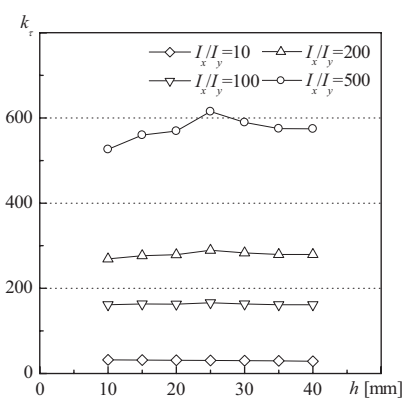

(b) せ九断座屈係数-波高
図18 曲げ剛比によるせん断座屈係数評価

するため, 曲げ剛比 $I_{x} / I_{y}$ を一定とし, 板厚 $t$, 波高 $h$ を変化させ, せ 几断座屈係数 $k_{\tau}$ への影響を見る. 図 18 は, RCP_10_4P/S試験体に おいて, $I_{x} / I_{y}=10 ， 100 ， 200 ， 500$ のつの值をとるように板厚, 波 高をそれぞれ調整したものである。この曲げ剛比の範囲は, 全体座 屈, 局部座屈が混在し問題が煩雑になることを避けるため, ある程 度, 全体座屈を形成するであろう範囲に限定している. 図より, 曲 げ剛比 $I_{x} / I_{y}=500$ では, せん断座屈係数 $k_{\tau}$ に若干のばらつきがあるも のの, 板厚, 波高に拘らず, せん断座屈係数 $k_{\tau}$ は, 曲げ剛比 $I_{x} / I_{y}$ を 用いて評価することが可能であると言える.

図19 は, 代表的な断面タイプ, 境界条件における全ての板厚, 波 高のせん断座屈係数 $k_{\tau}$ と曲げ剛比 $I_{x} / I_{y}$ の関係を表している. 又, 波 形鋼板の局部座屈の指標之なる帯板の四辺単純支持及び四辺固定支 持 ${ }^{15)}$ におけるせん断座屈係数 ${ }_{4 \mathrm{P}} k_{\tau, \mathrm{L}},{ }_{4 \mathrm{C}} k_{\tau, \mathrm{L}}$ も同図中に併せて示してい る. 座屈モードは前述の3 種に分けてある. 図より, 波形鋼板のせ 几断座屈耐力は, 曲げ剛比が小さい範囲では, 全ての試験体におい て板厚, 波高によらず曲げ剛比の増加に伴い座屈耐力が上昇する傾 向にあることがわかる.その後は連成座屈が生じ始めるにつれ, 曲 げ剛比に伴う座屈耐力上昇の度合は低下し,4C/Sではある一定の值 を保つものの, 4P/Sでは, 曲げ剛比の増加に伴い座屈耐力は減少し ていく. 局部座屈について見ると, 波形鋼板の局部座屈は通常, 帯 板の折線をヒンジと見なした四辺単純支持のせん断座屈として取り 扱われるが, $4 \mathrm{C} / \mathrm{S}$ ではそれ以上の境界条件の拘束が得られているも のの, 4P/Sではその評価式は局部座屈を過大評価するため検討が必 要になる.

また, 図 20 に示すように, 先の面外二方向に凸の RCP_10 につ いて, せん断座屈係数に対する曲げ剛比の影響を見ると, 曲げ剛比 $\left(\mathrm{I}_{x} / \mathrm{I}_{\mathrm{y}}\right)$ が四辺固定では約 500 以下, 四辺単純では約 100 以下の範囲 


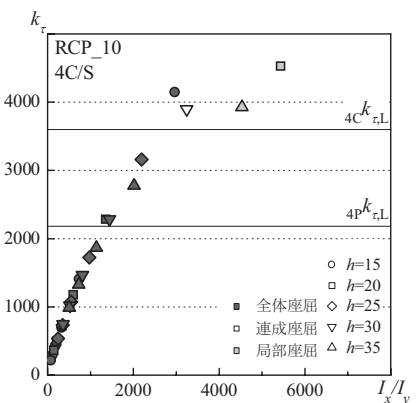

(a) $\mathrm{RCP} 10 \quad 4 \mathrm{C} / \mathrm{S}$

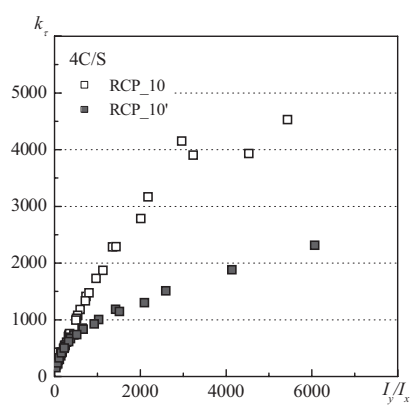

(a) 四辺固定 $(4 \mathrm{C} / \mathrm{S})$

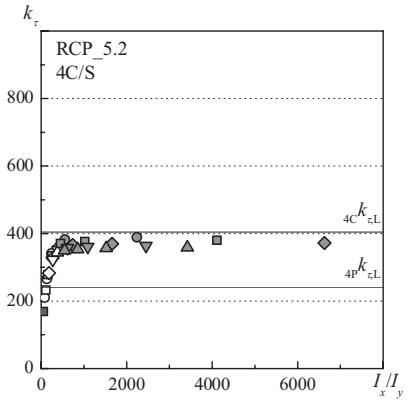

(b) RCP $5.2 \quad 4 \mathrm{C} / \mathrm{S}$

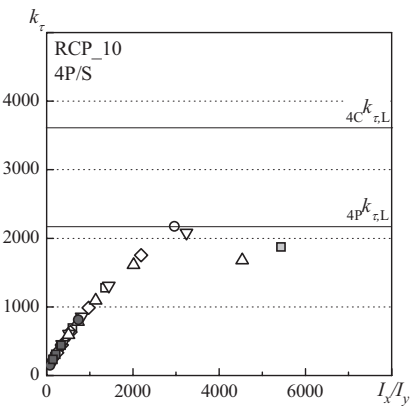

(c) $\mathrm{RCP} 10 \quad 4 \mathrm{P} / \mathrm{S}$

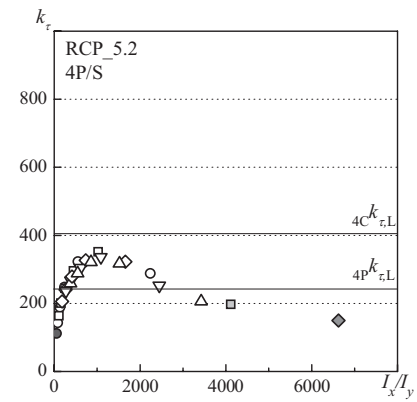

(d) RCP $5.2 \quad 4 \mathrm{P} / \mathrm{S}$

図 19 せん断座屈係数一曲げ剛比 (板厚, 波高の影響)

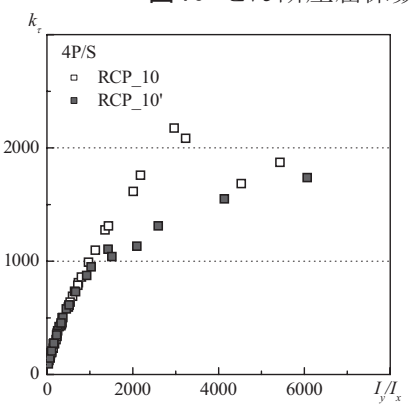

(b) 四辺単純 $(4 \mathrm{P} / \mathrm{S})$

図20 せん断座屈係数-曲げ剛比(荷重偏心の影響)

では，四辺固定，四辺単純ともに，RCP 10 と同一線上に乗ってい

る.ただし，RCP_10より曲げ剛比が低い範囲で連成座屈が生じ始 め, 座屈耐力の上昇度合が低下していくのが確認できる.

上述の曲げ剛比に伴う座屈耐力上昇の傾向について座屈モードと の関係から詳細に調べる.図 21 は 1 次モードの面外変形及び中央部 (太線), 端部付近 (細線)の波形断面形状を示している.曲げ剛比が 等しい場合, 波形, 断面ともにほぼ等しいが $((a),(b))$, 曲げ剛比が 増加すると，座屈波形の数が多くなる ((a), (c)). これは強軸方向の 剛性の相対的な増加により低次モードの座屈が拘束されたためと考 えられる。また, (c)は波形側面の据れも大きい. 断面タイプの異な るものについて比較すると $((\mathrm{c}),(\mathrm{d}))$, 曲げ剛比がほぼ等しいにも拘 らず(d)は波形断面端部付近で局部座屈を形成している.

\section{2 断面タイプの影響及び座屈耐力近似評価}

これら断面タイプが座屈耐力に及ぼす影響について考察する.全 ての試験体の全体座屈及び連成座屈のせん断座屈係数-曲げ剛比関 係を図 22 に示す. 図より, 矩形波形鋼板の座屈耐力は, 四辺固定, 四辺単純ともに, 全体座屈を形成する範囲においては断面タイプに よらず曲げ剛比に伴いほぼ同一線上に座屈耐力が上昇していく傾向

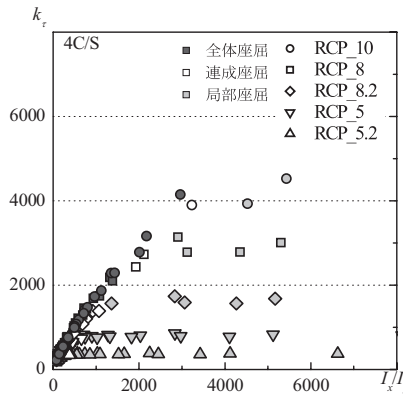

(a) 四辺固定 $(4 \mathrm{C} / \mathrm{S})$

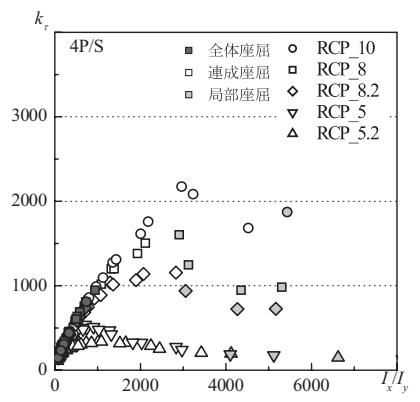

(b) 四辺単純 $(4 \mathrm{P} / \mathrm{S})$

図22 せん断座屈係数一曲げ剛比 (断面タイプの影響)

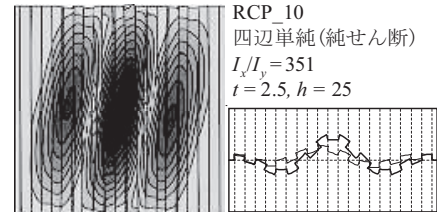

(a) RCP_10_4P/S- (1)

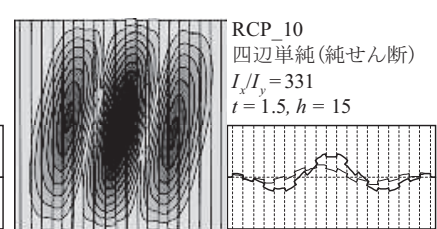

(b) $\mathrm{RCP} \_10 \_4 \mathrm{P} / \mathrm{S}-(2)$

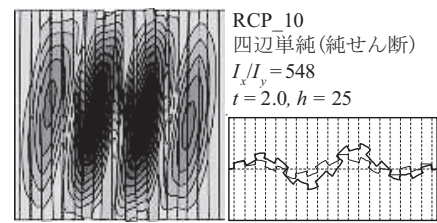

(c) RCP_10_4P/S- (3)

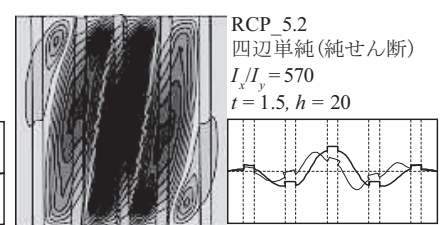

(d) $\mathrm{RCP} 5.2 \_4 \mathrm{P} / \mathrm{S}$
図21 座屈モード及び断面変形形状

にあり, 波密度が荒く波幅が不均等なものほど, 曲げ剛比が低い範 井で連成座屈を生じ始める. 全体座屈耐力について, 上述の傾向を 近似評価すると以下のような近似式が得られ, その対応関係を図 23 に示している.

$$
\begin{aligned}
& { }_{4 \mathrm{C}} k_{\tau, \mathrm{G}}=5.95 \times\left(\frac{I_{x}}{I_{y}}-1\right)^{0.82}+14.58 \quad \text {. . . . . . }(13) \\
& { }_{4 \mathrm{P}} k_{\tau, \mathrm{G}}=4.38 \times\left(\frac{I_{x}}{I_{y}}-1\right)^{0.79}+9.43 \quad \text {. . . . . . }(14)
\end{aligned}
$$

上式は曲げ剛比が 1 のとき, 平板のせん断座屈係数を満たす.ただ し, 連成座屈モードを形成し始め, 曲げ剛比に伴う座屈耐力の上昇 の度合が低下しない範囲, すなわち, 式(13), (14)が適用できる範 囲は断面タイプにより異なるが, $4 \mathrm{C} / \mathrm{S}, 4 \mathrm{P} / \mathrm{S}$ とに, 帯板の四辺単 純支持の場合のせん断座屈係数を用いて概ね次の式で表される.

$$
I_{x} / I_{y} \leq 0.167\left(_{4 \mathrm{P}} k_{\tau, \mathrm{L}}-9.34\right)+0.00058\left(_{4 \mathrm{P}} k_{\tau, \mathrm{L}}-9.34\right)^{2}+1
$$

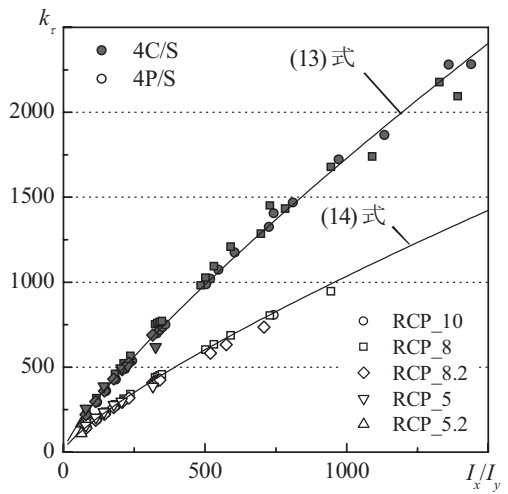

図23 座屈耐力近似評価式 


\section{3 境界条件の影響}

最後に, 図24において境界条件が座屈耐力に及ぼす影響につい て検討する. 全体座屈を形成する曲げ剛比の小さい範囲において は, 座屈耐力の上昇度合いは異なるものの全ての境界条件で一定の 傾向で増加していくが, $2 \mathrm{C} 2 \mathrm{P} / \mathrm{SB}, 4 \mathrm{P} / \mathrm{SB}$ は曲げ応力の影響により 曲げ剛比が比較的小さい範囲で座屈耐力上昇の度合いが低下してい る. 全体座屈を形成する試験体に関して, 図 25 に示すよう $4 \mathrm{C} / \mathrm{S}$ と $2 \mathrm{C} 2 \mathrm{P} / \mathrm{SB}$ 及び $4 \mathrm{P} / \mathrm{S}$ と $4 \mathrm{P} / \mathrm{SB}$ の対応を見ると, 面内変形を許容した 場合, 座屈耐力は純せん断の耐力に 0.8 を乗ずればよいことがわか る.但し, 同形状の試験体でも境界条件により連成座屈の生じ易さ は異なる。

\section{6. 結}

本研究では, 矩形形状を有する波形鋼板について, 有限要素法に よるパラメトリック解析を行い, 種々の波形形状及び周辺支持条件 におけるせん断座屈耐力の評価を試みた.

波形鋼板のせん断座屈耐力は, 板厚の増加とともに放物線的に増 加し, 波高の増加に従いせん断座屈耐力は上昇するが, 連成, 局部 座屈が生じる場合には, 同じ板厚でも波高が高い試験体の方が逆に せん断座屈耐力が低い值を示す.

全体座屈が生じる試験体を視認により選別し,そのせん断座屈耐 力を現行の評価式及びエネルギー法を用いた理論解析と比較検討し たところ,数值解析結果はこれら二つの評価法よりも高い值を示し た.その相対的な差は板剛度比が高い程大きくなる傾向がある.波 形鋼板の座屈耐力が異方性平板として扱った場合のそれを上回る要 因としては, 現状, 側部帯板によるせん断抵抗や㨝り剛性評価の違 いが可能性として挙げられる。

波形鋼板のせん断座屈耐力を適切に評価するに当たり,曲げ剛比 を用いて評価することを試みた. 結果, 板厚, 波高の影響によらず 座屈耐力は,曲げ剛比が大きくなるにつれて連成, 局部座屈を含め て一定の上昇傾向を示すことが明らかとなった.全体座屈耐力に関 しては, 四辺固定, 四辺単純ともに, 断面タイプ, 即ち波数及び波 形の上下帯板幅によらず曲げ剛比を用いて評価でき, 曲げ剛比を用 いた簡便な近似評価式を提案した。これらの式は,等方性平板の場 合にも適用できるように考慮したものであり,十分な精度を有して いる.また, 波形断面と垂直な二辺の面内変位を許容した場合, 全 体座屈を形成するものに関しては座屈耐力は波形断面端部の固定, 単純支持にかかわらず,ともに 0.8 を乗ずれば十分に評価できるこ とを示した。

なお本論文では数值解析による検討を中心に考察を進めてきたが, この結果と実験との対応なども今後検討していく必要があると考え ている.

\section{参考文献}

1) European Recommendations for the Application of Metal Sheeting Acting as a Diaphragm, European Convention for Construction Steelwork, 1995

2) Diaphragm Design Manual Third Edition, Steel Deck Institute, 2004.9

3) 波形鋼板ウェブ合成構造研究会: 波形鋼板ウェブPC橋 設計実例集2006, 2006.5

4) 帖佐和人, 柏井康彦, 河野進, 渡邊史夫 : 波形鋼板ウェブを耐震壁として 用いるための基礎的研究, 日本建築学会大会学術梗概集 C- I, pp.721$722,2006.9$

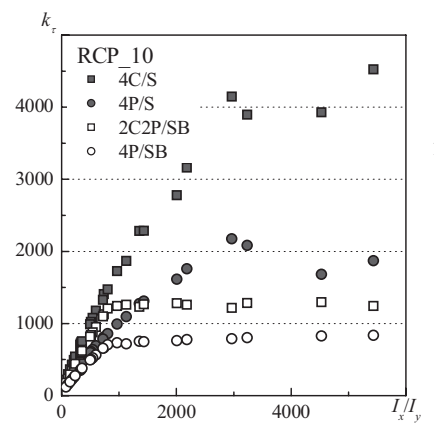

(a) RCP 10

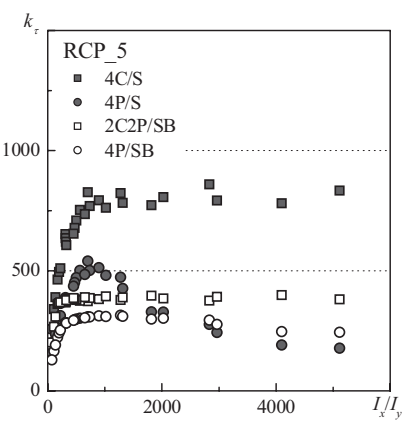

(b) RCP 5
図24 せん断座屈係数-曲げ剛比(境界条件の影響)

$$
k_{\tau}
$$

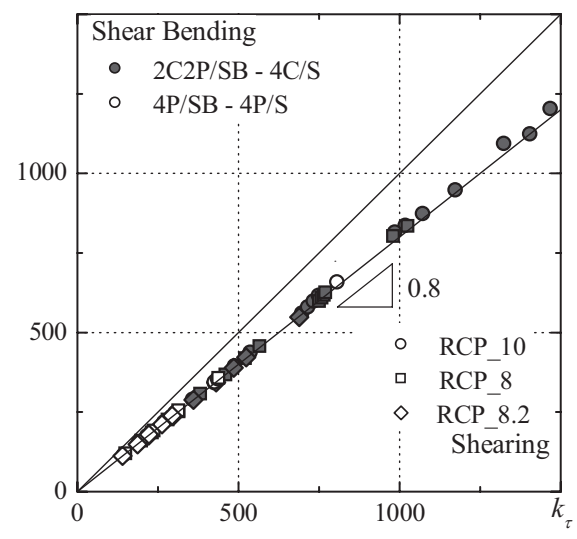

図25 曲げの影響による座屈耐力減衰率

5) 麻生直木 他 : 波形鋼板耐震壁の力学性状に関寸る研究 (その 1 、その2) 日本建築学会大会学術梗概集 C- I , pp.1123-1126, 2006.9

6) 池田崇他: 波形鋼板耐震壁の力学性状に関する研究 (その3〜その5), 日 本建築学会大会学術梗概集 C- I , pp.1121-1126, 2007.8

7) 笠直介, 市岡有香子, 花房広哉, 河野進, 渡邊史夫, 太田義弘 : 波形鋼板 ダンパーを組み込んだプレキャストPC閏型架構の力学的性状 (その 1 〜 その 3), 日本建築学会大会学術梗概集 C- I , pp.839-844, 2007.8

8) 富澤義人, 五十嵐規矩夫 他 12 名: 薄板鉄鋼材料を用いた鋼構造建築物の 可能性の探求と開発, 鋼構造シンポジウム2007 特別セッション 2 , 日本 鋼構造協会, 2007,11

9) Easley J. T., and McFarland D. E. : Buckling of Light-Gage Corrugated Metal Shear Diaphragms, Journal of the Structural Division, ASCE, Vol.95, No.ST7, Proc. Paper 6683, July, 1969, pp.1497-1516

10) Bergmann V. S. and Reissner H. : Neuere Probleme aus der Flugzeugstatkk, Zeitschrift Flugtech und Mororluftsch, Vol.20, 1929

11) Hlavacek V. : Shear Instability of Orthotropic Panels, Acta Technica CSAV, Prague, Czechoslovakia, No.1, 1968

12) Easley J. T. : Buckling Formulas for Corrugated Metal Shear Diaphragms, Journal of The Structural Division, ASCE, No.ST7, pp.1403-1417, July 1975.7

13) Bleich Friedrich : Buckling Strength of Metal Structures, Engineering Society Monographs, Mc-GRAW-HILL, pp.390-399, 1952

14) 呂 華峰,五十嵐 規矩夫, 王 蓞, 藤澤 逸志：材料異方性を持つ平板の 弾性座屈耐力に与える剛性及び境界条件の影響, 日本建築学会大会学術 講演集 C- I , pp.661-662, 2007.8

15) 五十嵐規矩夫, 鈴木玩也 : 逆対称曲げを受けるウェブ平板の弾性座屈而 力に及ぼす境界条件の影響, 日本建築学会構造系論文集, 第 571 号, pp.145-152, 2003.9

16) 日本建築学会 : 鋼構造座屈設計指針, 1996.1 